TRABAJOS DE PREHISTORIA

67, N. $^{\circ}$ 2, julio-diciembre 2010, pp. 489-499, ISSN: 0082-5638

doi: $10.3989 /$ tp. 2010.10052

\title{
Metals from the ritual site of Shaitanskoye Ozero II (Sverdlovsk Oblast, Russia)
}

\author{
Metales del yacimiento ritual de Shaitanskoye Ozero II (Provincia de Sverdlovsk Oblast, \\ Rusia) (1)
}

\author{
Olga Nikolaevna Korochkova $(*)$ \\ Serguei Vladimirovich Kuzminykh $(* *)$ \\ Yuri Borisovich Serikov $(* * *)$ \\ Vladimir Ivanovich Stefanov (*)
}

\begin{abstract}
The present article describes materials from the ritual site of Shaitanskoye Ozero II, Sverdlovsk Oblast. Few excavations carried out at the site measuring less than 240 sq. $\mathrm{m}$ in size, yielded more than 160 bronze artifacts: utensils, weapons, rolled copper ornaments, and abundant smelting and casting waste. Apart from Seima-Turbino (celts and laminar knives) and Eurasian types (daggers with cast hilts, truncated knives with guards, fluted bracelets and rings), several metal artifacts were revealed manufactured in the style of the Samus-Kizhirovo tradition. Bronze artifacts, stone knives and scrapers, and numerous arrowheads are accompanied by ceramics of the Koptyaki type. Metals use mainly a copper-tin alloy. This assemblage is shown to be relevant to the local tradition of metalworking, which, in this particular region, was comparatively ancient having been left uninterrupted by the rapid migrations of the Seima-Turbino people. In addition, the assemblage indicates the sources from which post-Seima artifacts reached the Alakul people. These artifacts may also have been linked with a large metalworking center located in the Middle Urals.
\end{abstract}

\section{RESUMEN}

Este artículo describe los materiales del sitio ritual de Shaitanskoye Ozero II, Provincia de Sverdlovsk. Las

(1) Supported by the Russian Foundation for Basic Research (Projects 10-06-00405-a, 08-01-00073a, and 08-0600136a)

(*) Ural State University, Lenina 51, Yekaterinburg, 620083, Russia. Correo electrónico: olga.korochkova@usu.ru

(**) Institute of Archaeology, Russian Academy of Sciences. Dm. Ulianova 19, Moscow, 117036, Russia. Correo electrónico: kuzminykhsv@yandex.ru reducidas excavaciones emprendidas en el lugar con superficie inferior a los $240 \mathrm{~m}^{2}$ han entregado más de 160 objetos de bronce: utensilios, armas, adornos en espiral de cobre y abundantes residuos de la fusión y el trabajo del metal. Además de tipos Seima-Turbino (hachas tubulares y cuchillos planos) y Euroasiáticos (puñales de mango fundido, cuchillos con empuñadura de lengüeta, brazaletes y anillos acanalados), varios artefactos metálicos resultaron manufacturados según el estilo de la tradición Samus-Kizhirovo. Los artefactos de bronce, los líticos (cuchillos, raspadores y numerosas puntas de flecha) están acompañados por cerámicos de tipo Koptyaki. El metal es generalmente una aleación de cobre y estaño. Este conjunto se considera relevante en la tradición local de trabajo del metal que, en esta región particular, era comparativamente antigua y quedó interrumpida por las rápidas migraciones de la gente Seima-Turbino. Además, el conjunto muestra las fuentes a partir de las cuales los artefactos post-Seima llegaron a la gente. Tales artefactos pueden relacionarse también con un gran centro de trabajo del metal localizado en los Urales centrales.

Key words: Bronze Age; Urals; Seima-Turbino; Samus- Kizhirovo; metalworking; Koptyaki culture; ritual sites.

Palabras clave: Edad del Bronce; Los Urales; SeimaTurbino; Samus-Kizhirovo; trabajo del metal; cultura Koptyaki; sitios rituales.

(***) Nizhny Tagil State Social-Pedagogic Academy, Krasnogvardeiskaya 57, Nizhny Tagil, 622031, Russia. Correo electrónico: serikov2@yandex.ru

Recibido: 30-VI-2010; aceptado: 14-IX-2010. 


\section{INTRODUCTION}

The Seima-Turbino type metal assemblage is distinct in terms of technology, morphology, and alloy. It serves as key evidence of the beginning of the Late Bronze Age in regions lying to the east and west of the Urals. Most Seima-Turbino bronzes have been found at large cemeteries such as Preobrazhenka-6, Rostovka, Satyga, Turbino, Ust-Vetluga, Seima, and Reshnoye; at small cemeteries and sites which are tentatively described as cemeteries (Verkhnyaya Mulga, Yelunino I, Tsygankova Sopka, Sopka-2, Bor-Lionva, UstGaiva, Murzikha-1, Sokolovka, Nikolskoye, and Hangaskankaala near Oulu, Finland); and ritual sites (Kaninskaya Cave and the Galich "hoard") in the forest-steppe and taiga regions of Western Siberian and the Russian Plains (Fig. 1). Synchronous sites in the steppe belt of the Southern Urals fall within the distribution area of the Abashevo and Sintashta cultural traditions, the metalworking of which absorbed the standards of the Circumpontic Metallurgical Province of the Early and Middle Bronze Age (Chernykh et al. 2002).

It is not clear why Seima-Turbino artifacts are so exceptionally rare in the middle Trans-Ural area and in the adjoining regions of Western Siberia. As a result, the ways in which the Ural mountain forest and taiga cultures became part of the Late Bronze Age, Eurasian Metallurgical Province also remain unclear. These issues are complicated by the fact that no Early Bronze Age sites synchronous with either Abashevo-Sintashta or Seima-Turbino have been discovered in the forest part of the Trans-Ural region. Allegedly, Early Bronze Age artifacts (mostly pottery) of the Karasie Ozero (Chairkina 2005: 195, 297) and Yelizavetino types (Panina 2004) are few making it dificult to correlate them with any reliable stratigraphic sequence. In addition, no information is available to determine when the exploitation of the numerous copper ore sites in the Middle Urals began.

The post-Seima period is also unmarked by cultural or chronological indicators, as is also the case with the period up until the emergence of the Andronov-type culture in the Urals, Cherkaskul. The only culture shown to fill the gap is the Koptyaki culture which was frst described by K.V. Salnikov (1964: 7-10). The Koptyaki people were long viewed as a minor group of the local mountain-forest population who were strongly

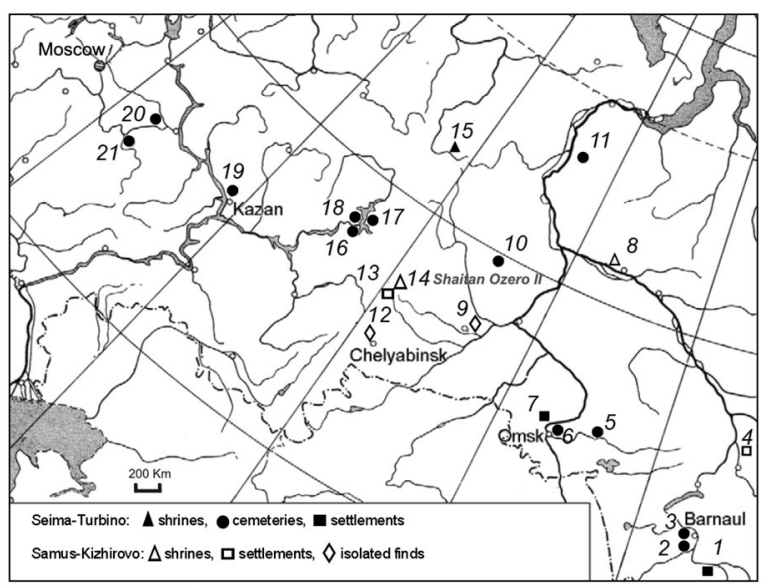

Fig. 1 (i). Seima-Turbino (O) and Samus-Kizhirovo ( $\mathbf{A})$ sites in Northern Eurasia: shrines (n. $\left.{ }^{\circ} 4,8,14,15\right)$, settlements (n. $\left.{ }^{\circ} 1,7,13\right)$, isolated finds $\left(n .^{\circ} 9,12\right)$, cemeteries (n. ${ }^{\circ}$ 2, 3, 5, 6, 10, 11, 16 a 21). 1 - Berezovaya Luka; 2 - Tsygankova Sopka; 3 - Elunino; 4 - Samus IV; 5 - Sopka-2; 6 - Rostovka; 7 - Chernoozerie VI; 8 - Saigatino VI; 9 - Andreyevskoye Ozero and to outline the; 10 - Satyga XVI; 11 - Tovkurtlor-3; 12 - Argazi; 13 - Palatki I; 14 - Shaitanskoye Ozero II; 15 - Kaninskaya Cave; 16 - Turbino; 17 - Bor-Lenva; 18 - Ust-Gaiva; 19 - Ust-Vetluga (Yurino); 20 - Seima; 21 - Reshnoe.

influenced by their southern neighbors. Initially, information on the Koptyaki culture was scarce, and its accumulation proceeded slowly and inconsistently, making it impossible to provide a detailed description. Circumstances changed however, after the excavations carried out at Palatki I near Yekaterinburg (Viktorova 1999, 2001).

Palatki I is a stratified site proving extremely rich in cultural materials. Several burials and a dwelling were attributed to the Koptyaki culture, as were bronze artifacts found: fragment of a celt, a dagger-knife decorated in the characteristic Samus-Kizhirovo style, and a fragment of a casting mold for a similar dagger (Chernykh and Kuzminykh 1989: Fig. 65, n. ${ }^{\mathrm{o}}$ 6; 79, n. ${ }^{\mathrm{o}}$ 7; Viktorova 2001: Fig. 5, n. ${ }^{\circ} 11$; Kuzminykh 2001). The Koptyaki assemblage also includes stone artifacts and a large collection of pottery, which has significantly enriched our understanding of Koptyaki ceramics in comparison to the descriptions given by K.V. Salnikov, M.F. Kosarev, and L.P. Khlobystin. While previously Koptyaki ceramics were viewed as post-Ayat influenced by Andronov tra-

(i) Fig. 1 del poster al TESME. 
ditions (primarilyAlakul and partly Fedorov), now the group of vessels with characteristically fluted and incised designs can be associated with the local Uralian tradition (Viktorova 2001). New information on the Koptyaki ceramics has made it possible to attribute similar pottery from other sites in the Urals and Western Siberia (Denisov and Melnichuk 1991; Stefanov and Korochkova 2000; Zakh and Skochina 2006) and to outline the distribution area of the Koptyaki culture: from west to east it ranged from the Middle Kama to the Lower Tobol, and in a meridian direction, from Nizhny Tagil to the Kyshtym lakes. Judging by the concentration of finds, the Middle Urals were the focal area. However, despite the discovery of indicative bronze artifacts and casting molds at Palatki I and despite intense excavations in the Tyumen area of the Tobol basin (Zakh and Ivanov, 2006; Zakh and Skochina 2006; Skochina 2007), the position of Koptyaki sites in the system of Late Bronze Age cultures still requires clarification.

\section{SHAITANSKOYE OZERO II: CHARACTERISTICS OF THE SITE AND FINDS}

Recent discoveries on the shore of Lake Shaitanskoye (Kirovgrad Region of Sverdlovsk Oblast (Province) shed new light on the Late Bronze Age in the mountain-forest zone of the Trans-Ural area (Fig. 2). Excavations (Fig. 3), more than 240 sq. $\mathrm{m}$ in size, have yielded more than 160 bronze artifacts - both tools and arms: 8 complete and two fragmented celts; 19 knives and daggers; 5 adzes; 3 socketed hammers; 1 spear, 2 openwork hafts; a forged chisel; hooks; a dozen of awls, perforators, and tiny gouges; fragments of knives, celts, and spears (15 specimens); a spearhead model; etc. (Serikov et al., 2009). The collection also comprises decorations mostly made of sheet copper (fluted bracelets including specimens with spiral ends; complete and fragmented temple rings) and by-products of melting and casting. Bronze artifacts, stone knives, scrapers, and numerous arrowheads were found in association with Koptyaki ceramics. The high concentration of bronze and stone artifacts in a small area represents a specific feature of this site. The site itself is located on one of the western promontories at an elevation of approximately 1.5-2

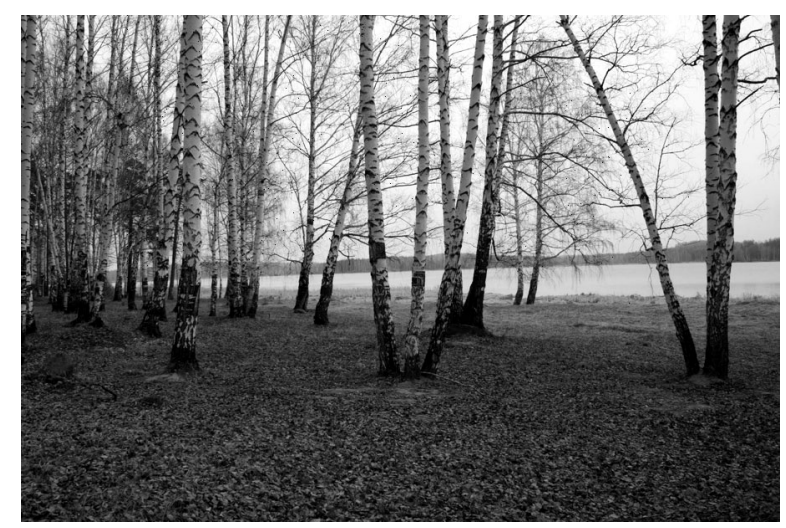

Fig. 2. Shaitanskoye Ozero II ritual place. Southwest view of the site.

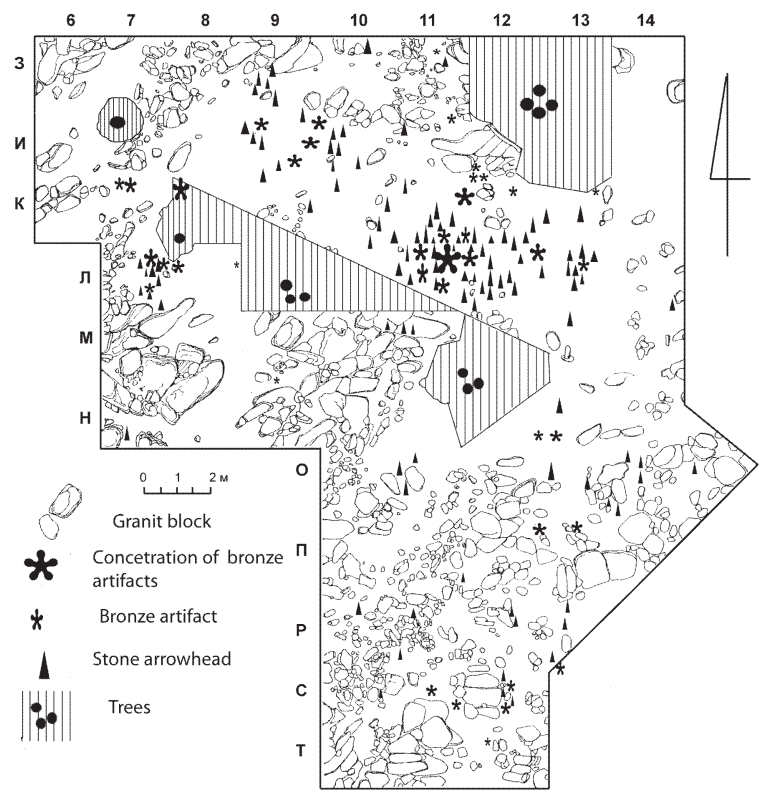

Fig. 3. Plan of the excavation Shaitanskoye Ozero II (ii).

$\mathrm{m}$ above the lake surface (Fig. 3). This is a small, shallow running-water lake (surface area approx. 1.48 sq. $\mathrm{km}$ ) with flat, mostly swampy shores. In some areas, wooded hills reach close to the shoreline.

Artifacts were discovered at a shallow depth $(10-45 \mathrm{~cm}$ from the surface) in a layer of light brown loam separately, in pairs or in large and small clusters (Fig. 4). The largest cluster occupying an area of 7 sq. $\mathrm{m}(\mathrm{L} / 11-12)$. Its core was

(ii) Pendiente de recibir versión con la rotulación traducida al inglés.

T. P., 67, N. ${ }^{\circ} 2$, julio-diciembre 2010, pp. 489-499, ISSN: 0082-5638 doi: $10.3989 /$ tp.2010.10052 


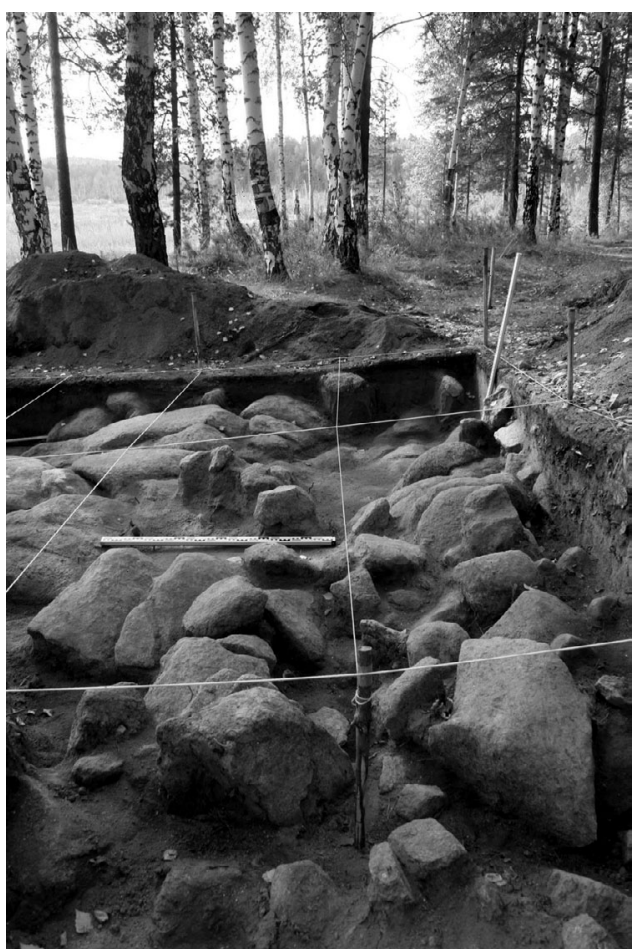

Fig. 4. Shaitanskoye Ozero II: southwest corner of the excavation (square S, T-10, excavation 2009).

represented by a compact group of artifacts: three bronze knives, two slotted hafts, a broken celt, two spearhead fragments, a hook, two tetrahedral points and fragments of fluted bracelets. Another four bronze knives were encountered 1.2-2 $\mathrm{m}$ to the north-east and east of this cluster. The sediments between these artifact accumulations yielded numerous foundry by-products, small fragments of artifacts (probably, waste), including celts, hooks, grooved bracelets, and about 70 triangular, stone arrowheads.

A complex comprised of a tiny celt, a knife, six stone arrowheads, and a spearhead broken into two parts was found east of the cluster mentioned above. Another small concentration was found located to the north-west of the largest cluster and included a celt, a socketed hammer, and a spearhead model. A vertically placed dagger was also found in the vicinity; 18 arrowheads were located 1.2- $1.5 \mathrm{~m}$ from the bronze artifacts comprising the smaller cluster. A set of three items placed one inside the other is particularly noteworthy: a celt was found stuck into the ground with a hammer in it and a hook inserted into the hammer's socket.
Within the boundaries of exposed concentrations, artifacts were found mixed together at various depths. Metal implements were revealed resting on their edges, lying at an angle or even vertically. Large clusters were formed gradually. It is highly unlikely that these items were placed on the ground. They seem rather to have been placed in small depressions dug into loose sediments and between stones, and then covered with earth. Numerous potsherds and isolated stone artifacts mark the day surface of the site.

The metal implements from Shaitanskoye Ozero II can be morphologically subdivided into three groups. The group of Seima-Turbino artifacts is comprised of lamellar double-edged knives with slightly marked or no tang (Figs. 5, n. ${ }^{\circ} 3-5,8-10 ; 6$, n. $\left.^{\circ} 8,9\right)$, adzes and other composite tools made of similar types of knives or their fragments (Fig. 7, n. ${ }^{\circ}$ 11, 13-15, 23). Lamellar knives and implements made from them are among the most typical and frequent finds in burials of the Seima-Turbino type and the Ka-

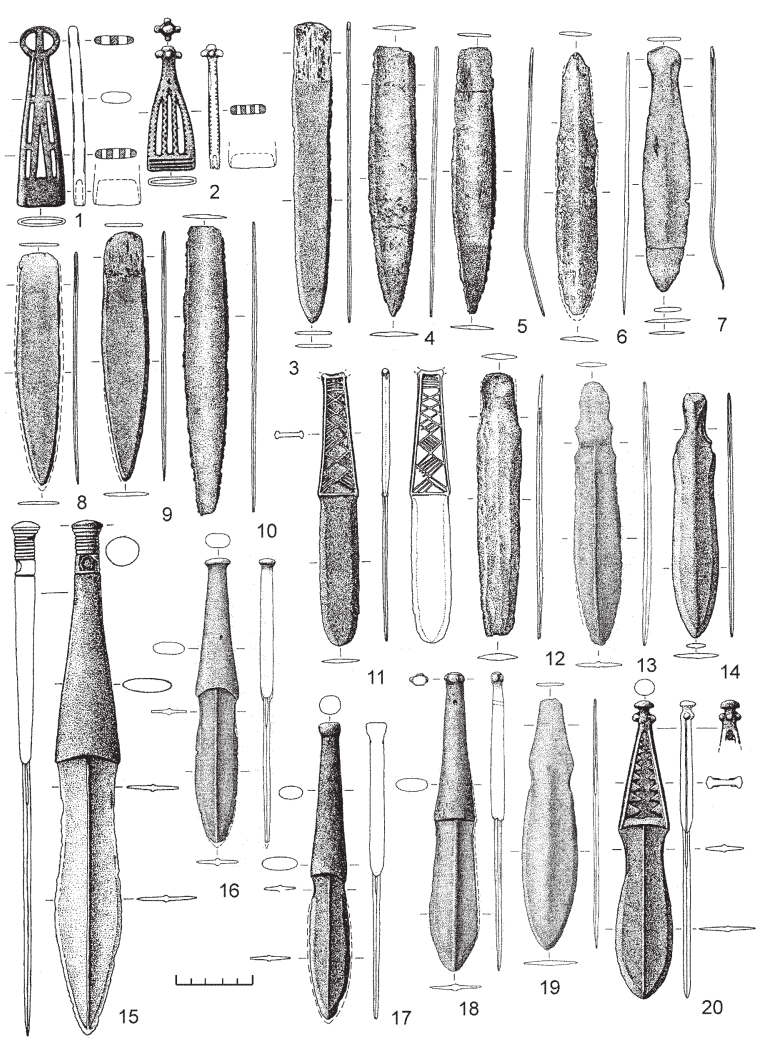

Fig. 5. Shaitanskoye Ozero II: metal assemblage (knives, daggers, and hafts). 


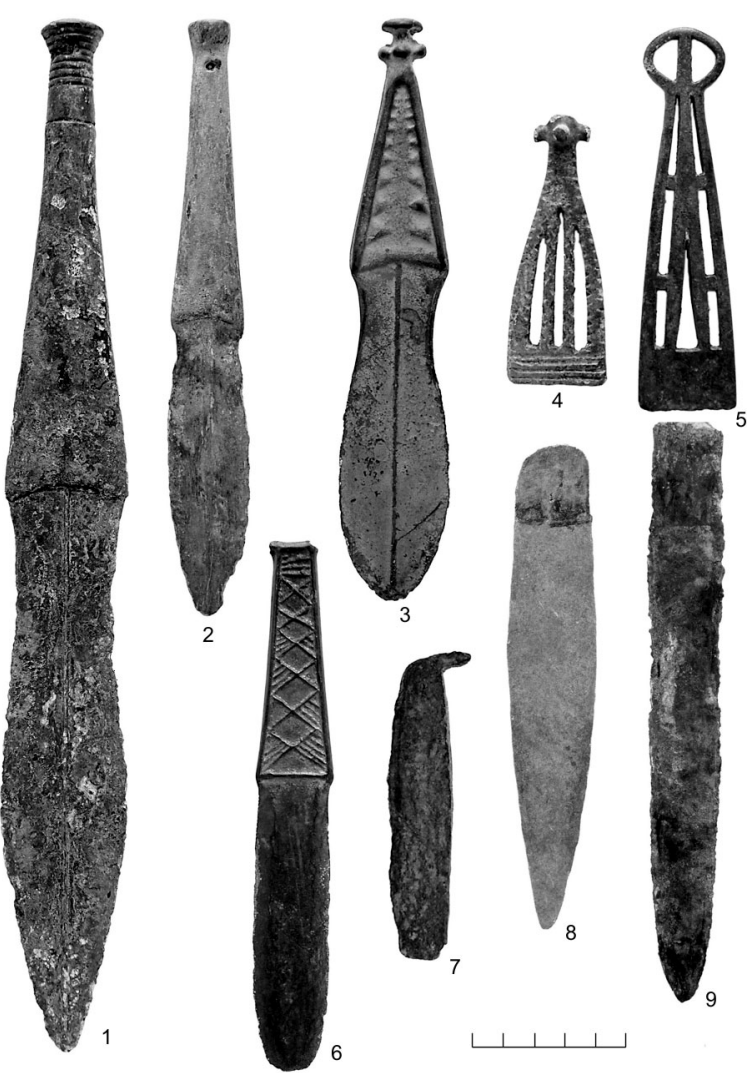

Fig. 6. Shaitanskoye Ozero II: metal assemblage (knives, daggers, and hafts).

ninskaya Cave sanctuary (Chernykh, Kuzminykh 1989: pl. 8). Two of the celts or rather its miniature model (Fig. 8, n. ${ }^{\circ}$ 5, 6) from Shaitanskoye Ozero II can be attributed to the Seima-Turbino type.

The Samus-Kizhirovo group of artifacts (Chernykh, Kuzminykh 1989: 144-162) includes celts with one or two false loops (Figs. 8, n. ${ }^{\circ} 1-4$, 10,$11 ; 9$, n. $\left.^{\circ} 1-5\right)$, a dagger with a broken top (most probably ring-shaped), a flat haft decorated with hatched triangles and rhombs on both sides, and a lamellar blade (Figs. 5, n. ${ }^{\circ} 11 ; 6$, n. $^{\circ} 6$ ). The group of artifacts of the Eurasian type, characteristic of the steppe and forest-steppe cultures of Northern Eurasia (Chernykh, Kuzminykh 1989: 184, pl. 17), is comprised of double-edged daggers with caston hafts including decorated examples (Figs. 5, n. ${ }^{\circ} 15-20 ; 6$, n. $^{\circ} 1-3$ ), models (?) of slotted hafts (Figs. 5, n. ${ }^{\circ} 1,2 ; 6$, n. $^{\circ} 4,5$ ), knives with quillons and crossbars (Fig. 5, n. $^{\circ} 13,14$ ), a forged chisel (Fig. 7, n. ${ }^{\circ} 8$ ), spearheads and their fragments (Fig. 7, n. ${ }^{\circ}$ 1, 2, 7, 12), lamellar fluted bracelets and rings (Fig. 7, n. ${ }^{\circ} 28-30,38-41$ ). This group includes numerous imported Petrovka-Alakul artifacts. Due to their unique character, some finds, particularly socketed chekan battle axes (Fig. 7, n. ${ }^{\circ} 3-5$ ) fail to correspond to any morphological group.

The chemical composition of 88 specimens representing the majority of the metal artifacts from Shaitanskoye Ozero II (analyses 4921249299) was examined by the Laboratory for Science-Based Methods at the Institute of Archaeology, Russian Academy of Sciences (Moscow) (Lunkov et al. 2009: 103-106). Almost all tools and weapons (excluding tiny fragments of knives) and many blanks and wastes of fusion and casting were examined. A series of delicate lamellar decorations awaits future analysis.

Several metallurgical (chemical-metallurgical) groups or alloy categories can be traced within the collection. Most artifacts (68 specimens or over $77 \%$ of the sample) are made of tin bronze. The tin concentration in the alloy ranges from $0.8-1.0$ to $10 \%$. Most artifacts are made of medium-alloyed metal with the tin concentration of 3-8\%. Approximately half of the artifacts (30 specimens) reveal an increased content (tenths of

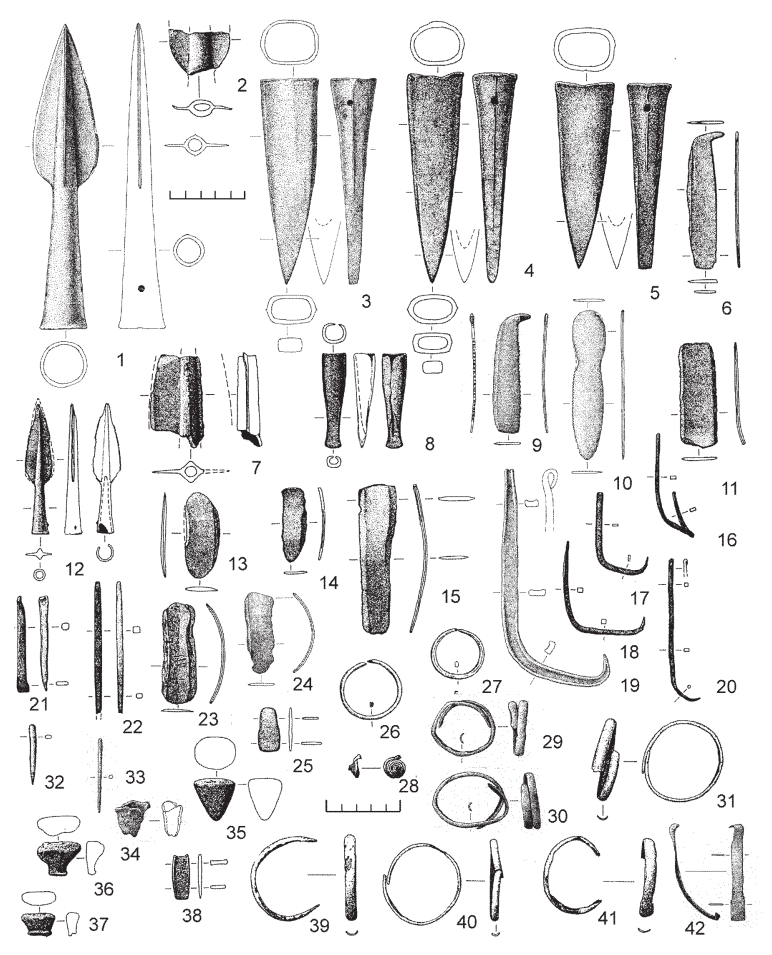

Fig. 7. Shaitanskoye Ozero II: bronze artifacts. 
a percent) of zinc ( 21 specimens), lead ( 4 specimens), and arsenic (1 specimen), and in some cases a mixture of these elements in different proportions (including antimony). This high rate of admixtures results either from alloying metal of different compositions or from the geochemical characteristics of copper which is the basic element of the alloy. Two more items may be tentatively attributed to the group of tin bronze artifacts: the haft of a dagger cast from a copper-tin-lead alloy (Fig. 5, n. ${ }^{\circ} 11 ; 6$, n. $^{\circ}$ 6) and a celt (Fig. 8, n. $\left.{ }^{\circ} 11\right)$ made of a copper-tin-arsenic alloy.

The Shaitanskoye Ozero II assemblage contains few implements made of metallurgically "pure" copper (17 specimens or less than $19 \%$ of the sample). Only three specimens are absolutely "pure" with an admixture quantity of a hundredth of a percent or less. Other artifacts contain (tenths of a percent) zinc (10 specimens) and tin (1 specimen), and in some cases a mixture of the latter with lead and nickel. Arsenic bronze is present in just one object: the arsenic proportion in the

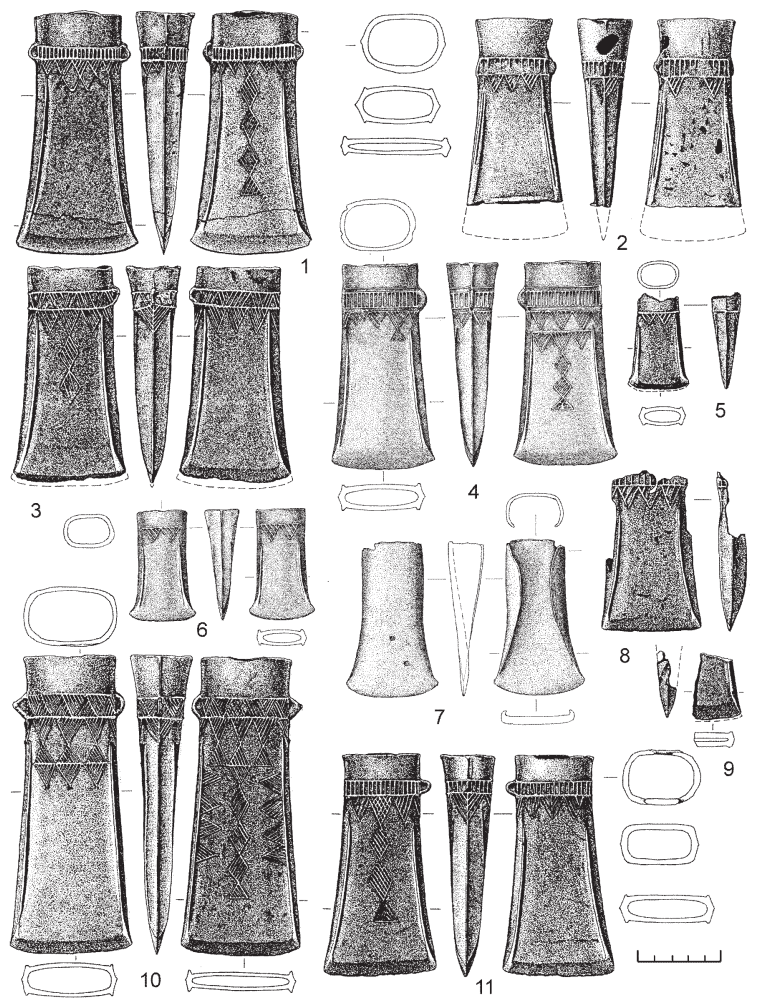

Fig. 8. Shaitanskoye Ozero II: celts. spearhead (Fig. 7, n. $^{\circ} 12$ ) reaches $2.16 \%$ and the zinc content is slightly increased $(0.43 \%)$.

The predominance of tin bronze in the Shaitanskoye Ozero II collection, including blanks and raw materials (ingots, drops, etc.), suggests that alloys, metal parts and implements themselves were received from manufacturing centers of the Andronov culture.

Manufacturing techniques of metal objects in Shaitan Ozero are reconstructed only through visual scrutiny. Metallographic research by A.D. Degtiareva has not finished yet. However, some technological operations might be identified considering several evidences of casting and forging.

Casting of blank objects and forging of tools and ornaments: This technique has been used in order to manufacture a socketed gouge (based on the hafted chisel) (Fig. 7, n. ${ }^{\circ}$ 8), thin awls and bars (Fig. 7, n. ${ }^{\circ}$ 21, 22, 31), hooks (both in bar-like and blank forms) (Fig. 7, n. ${ }^{\circ}$ 16-20), and some rings (Fig. 7, n. $^{\circ} 26,27$ ). On the first place, drafts were cast in bivalve or double-moulds. One of the valves was used as a matrix containing the blank's footprint, and the other one served as a cover. On the second place, forging had to be performed in order to finish the tools or rings concerned. Forging bar-like tools and rings was quite an easy task, but socketed tools (i.e. gouges and chisels) required two different steps: firstly, thinning one of the blank's ends that was next rolled in a tube-like mould, and, secondly, forging the other blank's end (the cutting edge) (Fig. 7, n. ${ }^{\circ} 8$ ).

Casting of blank fine fluted ornaments and their final manufacturing by forging: Fluted bracelets and temple rings (Fig. 7, n. ${ }^{\circ}$ 28-30, 39-42) were cast firstly as fine, long, flat sheets. Secondly, sheets were grooved using a special wooden carved mould. A wooden or metallic round-ended tool was employed in addition in order to fulfill the sheet's manufacture. Afterwards, holes were opened in every end, if necessary. Ends were then cut out and polished. Finally, the ornament was bent and given the desired form.

Casting of socketed objects employing bars: Bivalve moulds were used for casting all socketed objects recovered at the site, i.e.: celts (Fig. 8, n. ${ }^{\circ}$ 9), spearheads and their models (Fig. 7, n. $^{\circ} 1,2,7,12$ ), and a socketed Chekan battle axe (Fig. 7, n. ${ }^{\circ}$ 3-5). Both valves served as matrices, that is to say, both were carved symmetrically following the tools' or weapons' shapes. The socket was formed putting in a clay piece or

T. P., 67, N. ${ }^{\circ} 2$, julio-diciembre 2010, pp. 489-499, ISSN: 0082-5638

doi: $10.3989 /$ tp.2010.10052 
bar. Two holes or channels -usually with a convex or inverted umbrella-like form- were opened in the upper part of the mould. One of them was used to pour metal, employing a funnel, and the other one served to evacuate the generated gases as well as to control the pouring of metal.

Casting could be considered fulfilled if gases were completely evacuated from the second channel before metal appeared in it. In Shaitan Ozero 2 sanctuary there are piles of foundry by-products that were solidified both around the funnels (Fig. 7, n. ${ }^{\circ}$ 34) and in the channels (Fig. 7, n. $^{\circ} 35,36$ ) used for pouring metal in moulds probably aimed at casting celts.

Bivalve molds were used as well for casting the main knife series, which are by far the dominant class item in Shaitan Ozero's collection, whenever hilt and blade were cast at the same time. Usually, one valve served as the matrix and the other one as the cover (Figs. 5, n. ${ }^{\circ} 3-10,12-14$ y 6, n. $\left.^{\circ} 8,9\right)$. Hilt and edge were afterwards touched up by forging, but high tin-content objects' edges were in particular sharpened using stone abrasives. Regarding single-edged daggers with a curved blade and metallic hilt (Figs. 5, n. ${ }^{\circ} 11,20$ y 6, n. $^{\circ} 3,6$ ), both valves were matrices,

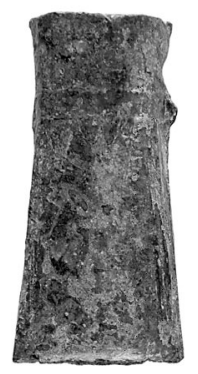

1
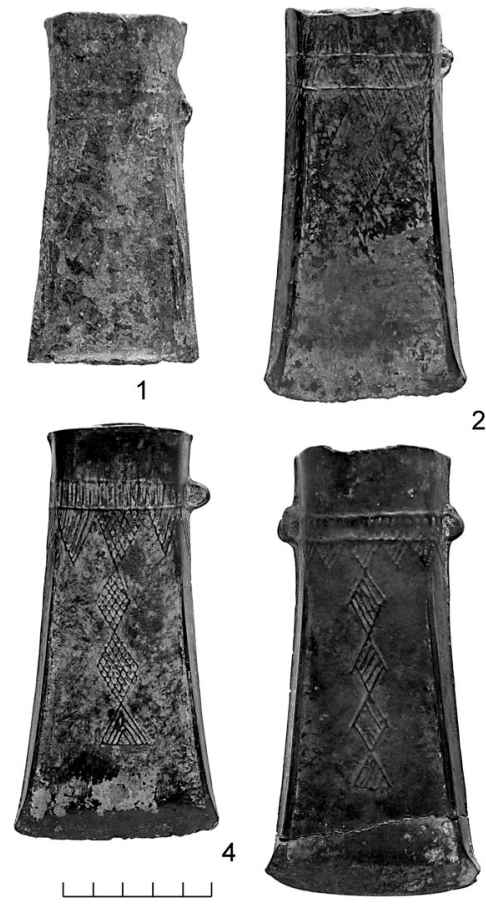

2
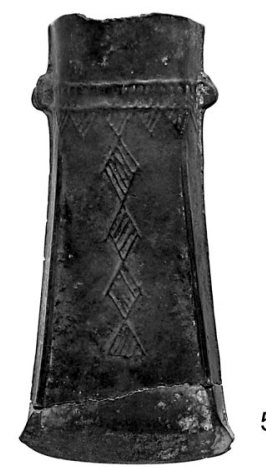

5

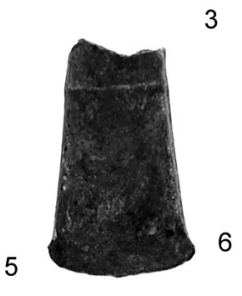

that is to say, both were carved symmetrically following the tools' shapes.

Casting single-edged daggers with a curved blade in two steps: Regarding these daggers (Figs. 5, n. ${ }^{\circ} 15-18$ y 6, n. $^{\circ} 1,2$ ), blades were cast firstly and, secondly, their upper parts, normally at the tang level, were put in a bivalve mould in order to cast the hilt. Daggers were thus made in two steps.

Whenever there did not remain any traces of burrs or their removal in the hilts, it could be assumed that the lost-wax casting technique was employed in order to manufacture them. The upper part of a recovered dagger's hilt (Figs. 5, n. ${ }^{\circ} 15$ y 6, n. $^{\circ} 1$ ) testified a faulty casting, probably due to a breaking of the wax model. As a result, the hilt's end was sawed, and a bar was added in order to make a new wax model for casting this upper part. This was already a third step in casting the dagger concerned.

Casting through lost-wax technique, employed for a couple of single-edged curved-blade daggers' hilt models (Figs. 5, n. ${ }^{\circ} 1,2$ y 6, n. $\left.{ }^{\circ} 4,5\right)$.

The lithic assemblage comprises more than 230 stone tools, 100 flakes, and 86 functionally indistinct objects (Figs. 10, 11). Arrow and dart points and their blanks (149 specimens) dominate the collection. Most are made of flint and chalcedony of various colors. Scrapers, blade tools, and fragments of polished tools are less numerous. Hammer stones, pestles (one is bootshaped), and grindstones are represented by small series or a single specimen. Arrowheads are mostly triangular with a straight, concave, or truncated base and are thoroughly worked with flat retouch. Just two tanged points are present. The excavation area revealed no traces of tool manufacture, arms or decorations. However, several intentionally broken bronze and stone implements were found. The Shaitanskoye Ozero lithic assemblage shares certain characteristic features with recorded Seima-Turbino complexes.

The bronze and stone artifacts discovered were accompanied by fragments (at least 2500 specimens) of more than 40 vessels (Fig. 12). All vessels were made of clay with a considerable admixture of talc particles. Notably, many pieces of talc were observed among the finds. The Shaitanskoye Ozero ceramic assemblage includes vessels of varying shape, size, and decoration.

Fig. 9. Shaitanskoye Ozero II: celts. 


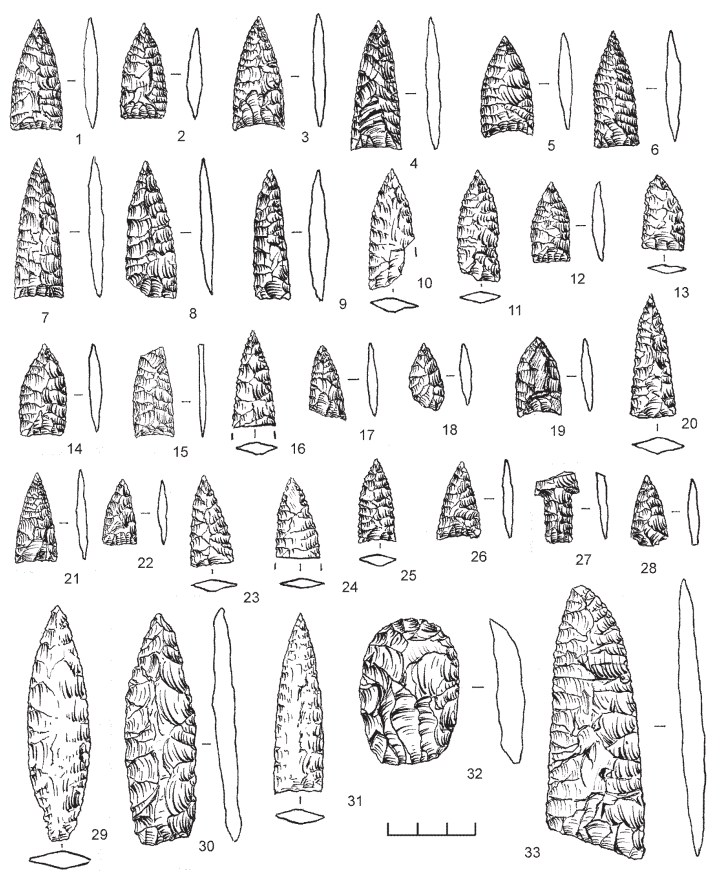

Fig. 10. Shaitanskoye Ozero II: stone arrowheads. Artifacts.

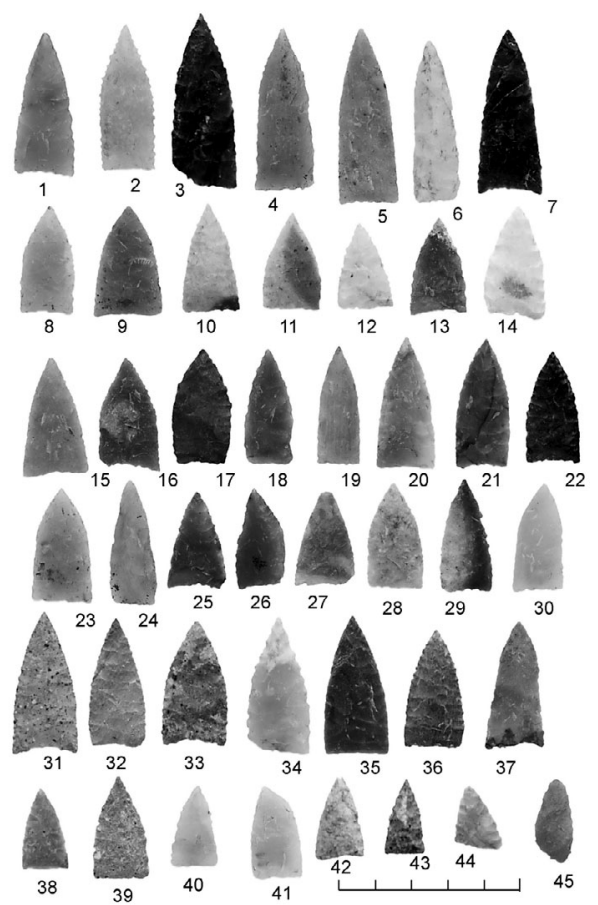

Fig. 11. Shaitanskoye Ozero II: stone arrowheads. Artifacts.

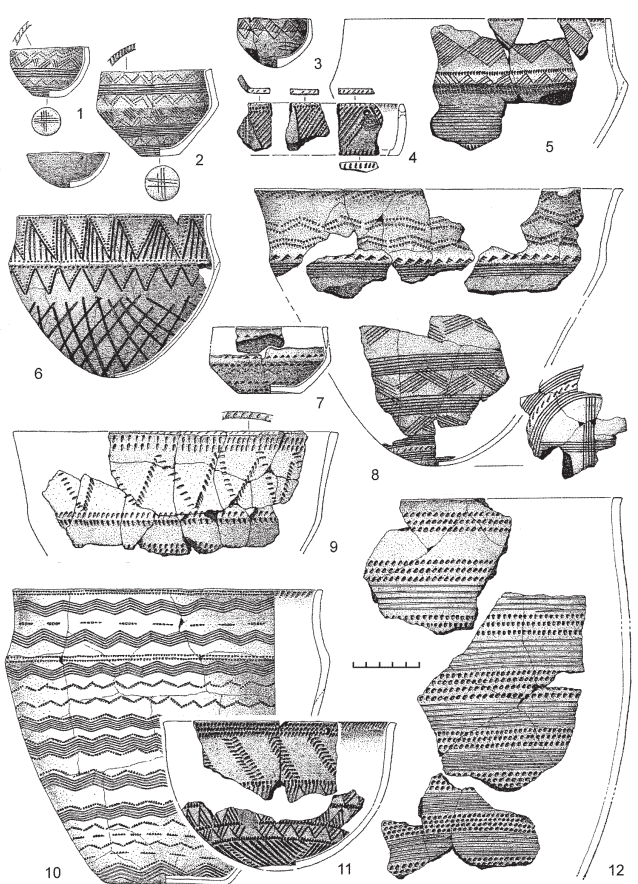

Fig. 12. Shaitanskoye Ozero II: ceramics.

Nonetheless, these artifacts comprise a single assemblage which is evidenced by the position of the fragments in the layer and in depressions; by the uniformity of certain basic technological and morphological characteristics; and by parallels identified with other assemblages of the Yekaterinburg and Tyumen regions. Shaitanskoye Ozero ceramics differ slightly from those of the Koptyaki type recorded at the Koptyaki- 5 settlement (Salnikov 1964: 7-10; Khlobystin 1976: 55-58; Kosarev 1981: 77-80; Obydennov and Shorin 1995: 25-30). Along with typical flat-bottomed vessels, the Shaitanskoye Ozero assemblage contains specific round-bottom jars and pots (Fig. 12, n. ${ }^{\circ} 6,8,11$ ) with wide mouth (Fig. 12, n. $\left.{ }^{\circ} 7,8,9\right)$, and ribbed and gently curving body (Fig. 12, n. $\left.{ }^{\circ} 2,5-10\right)$. It also includes several vessels decorated with comb impressions. Geometric motifs are few. However, horizontal incisions and grooves frequently occur in vessel decoration. Some vessels appear very archaic and as such may be attributable to the Chalcolithic period. Even a preliminary comparison reveals parallels with autochthonous Chalcolithic assemblages along with transformed features of the Andronov (Alakul and Early Alakul) ceramic tradition as well as indistinct Abashevo (or Abashevo-like) parallels.

T. P., 67, N. ${ }^{\circ} 2$, julio-diciembre 2010, pp. 489-499, ISSN: 0082-5638

doi: $10.3989 /$ tp.2010.10052 


\section{DISCUSSION}

While the study of the Shaitanskoye Ozero II ritual site was initiated relatively recently, the results strongly suggest that the site is highly relevant to the Late Northern Eurasian Bronze Age and that the mountain-forest Urals were a part of the Eurasian Metallurgical Province.

New data document the relationships between the two major components involved in that process, the eastern (Seima-Turbino proper) and the western (Eurasian). It should be stressed that the Shaitanskoye Ozero II metal assemblage is not completely congruous with the Seima-Turbino complex. Specifically, only one element of the Seima-Turbino triad (celts, bifurcated spearheads, and laminar knives) is represented in the case of laminar knives. Celts retain principal morphological (proportions and strengthening rib) and decorative (ladder-like belt with pendant triangles and diamonds) features of Seima-Turbino tools; however, they likewise demonstrate a departure from the canon in the shape of loops all of which are "false". This element is typical of Kizhirovo type celts (Chernykh and Kuzminykh 1989: figs. 77, n. $^{\circ} 7 ; 78 ; 79 ; 80$, n. $\left.^{\circ} 1-6\right)$, which, along with belted and loopless Samus celts (Chernykh and Kuzminykh 1989: figs. 75, 4, 4a; 76; 77, n. ${ }^{\circ}$ 1-5), are diagnostic of Samus-Kizhirovo metalworking. Such implements were distributed in the taiga regions of Western and Eastern Siberia from the Urals to Lake Baikal.

It would appear that the site, which was partially excavated in 2006-2009, was not a settlement. No evidence of any production activity has been recorded in the excavated area. Nor was it a burial ground, although remains of an infant burial were found in the 2007 excavation. Although the local soil is unfavorable for the preservation of organic matter, it is unlikely that bone remains having originally been present would have completely degraded. Alternatively, the site may have been a cenotaph, although such a suggestion is purely speculative. According to Yu.B. Serikov, Shaitanskoye Ozero was used as a place for hiding ritual objects. The abundance of metal waste is a significant feature; no stone waste has been discovered. Stone artifacts dating to the period in question were made of imported light and dark flint and chalcedony. These are strikingly distinct from Neolithic, Chalcolithic, and Early Iron Age Trans-Uralian artifacts.
While the concentration of excellently preserved copper and bronze artifacts in one place is remarkable, the real significance of the site lies elsewhere. Shaitanskoye Ozero demonstrates how the mountain-forest Urals became part of the Eurasian Metallurgical Province, and how the eastern (Seima-Turbino proper) and western (steppe, or Eurasian) components interacted.

Metal artifacts from Shaitanskoye Ozero II document the intertwining of various traditions at the initial stage of Samus-Kizhirovo metalworking. They show how Eurasian (Petrovka-Alakul) types were adopted and modified by local Koptyaki artisans. Borrowing could have been twoway, and replicas of artifacts manufactured in the mountain-forest centers like Shaitanskoye Ozero may have reached the forest-steppe, as evidenced by Trans-Uralian sites such as Korkino (Chemyakin, 2000: 30, fig. 13, 14), Stepnoye (Zdanovich and Kupriyanova 2007: fig. $1, \mathrm{n}^{\circ}{ }^{4}$, 5), Chernyaki (Stokolos 1972: figs. 9, n. ${ }^{\circ} 8 ; 10$, n. $^{\circ} 12$ ), and Vysokaya Griva (Potemkina 1985: 128, 129, fig. $10, \mathrm{n}^{\mathrm{o}}$ 12). In addition, metal artifacts from the Uralian centers may have been exported to the taiga area of the Ob-Irtysh interfluve, where the local Late Bronze Age metalworking tradition emerged thanks to this influence. Examples include the Saigatino VI sanctuary (Koksharov and Chemyakin 1991), the Tovkurtlor-3 burial ground (Stefanov 2006), and settlements such as Pashkin Bor, Volvoncha (Stefanova and Koksharov 1988; Koksharov and Stefanova 1993; Chernykh and Kuzminykh 1989: 144157), etc.

Generally, materials from Shaitanskoye Ozero II support the hypothesis proposed by E.N. Chernykh and S.V. Kuzminykh (1989) which states that the Seima-Turbino traditions played the key role in the origin of Late Bronze Age metalworking of the northern forest-steppe and taiga zones of the Urals and Western Siberia. New findings document the impact of the Middle Uralian and Western Siberian cultures on the formation of the Samus metalworking tradition.

Another important issue concerns the virtual absence of metal artifacts at Bronze Age sites, contrasting with the abundant evidence of metalworking including crucibles, ladles, and molds. Given that not only intact artifacts, but also waste was transported to ritual places such as Shaitanskoye Ozero, the absence of artifacts in settlement habitation layers is not surprising. 
Because the site has not been excavated in full, other arguments in favor of various versions may appear in the future. In our view, the site is best interpreted as a ritual or sacrificial site. Further multidisciplinary studies are clearly needed. Since the place is located close to copper ore sites, the relationship between the latter and Koptyaki metalworking deserves attention. The key tasks for future comprehensive studies are to reconstruct the environment, to locate sources of stone, etc. Issues linked with assessing the topography of the ritual space and its underlying ideology are no less important, but highly complex challenges (Serikov 2007a, 2007b; Serikov et al., 2009). In the light of new discoveries, the Koptyaki culture acquires the status of a major center influenced by Seima-Turbino and Petrovka-Alakul traditions. Its chronology, both absolute and relative, should be evaluated within the context of the Bronze Age metallurgical province. Preliminary observations on ceramics, stone tools, and the morphology and chemical composition of metal artifacts suggest that Shaitanskoye Ozero reflects the initial stage in the emergence of Alakul and Srubnaya (Timber-Frame) cultures and the progressively more intense northern affinities of the steppe populations.

\section{BIBLIOGRAPHY}

Chairkina, N.M. 2005: Eneolit Srednego Zauralya. Uralskoe otdelenie Rossijskoj Akademii nauk. Yekaterinburg.

Chemyakin, Yu.P. 2000: "Korkino I". In Uralskaya istoricheskaya entsiklopediya. Akademkniga, Uralskoe otdelenie Rossijskoj Akademii nauk. Yekaterinburg: 281-282.

Chernykh, E.N.; Avilova, L.I.; Orlovskaya, L.B. and Kuzminykh, S.V. 2002: "Metallurgiya v Tsirkumpontiiskom areale: Ot edinstva k raspadu". Rossiiskaya arkheologiya 1: 5-23.

Chernykh, E.N. and Kuzminykh, S.V. 1989: Drevnyaya metallurgiya Severnoi Evrazii (Seiminsko-Turbinski fenomen). Nauka. Moscow.

Denisov, V.P. and Melnichuk, A.F. 1991: "Zaosinovskoe VII poselenie i problema formirovaniya kultury epokhi bronzy v Srednem Prikame". In Pozdni eneolit i kultury rannei bronzy lesnoi polosy Evropeiskoi chasti SSSR. Arkheologiya i etnografiya Mariiskogo kraya 19. Respublikanskoe poligraficheski-redaktsionnoe obyedinenie Goskomizdata Mariiskoi SSR. Yoshkar-Ola: 102-113.
Khlobystin, L.P. 1976: Poselenie Lipovaya Kurya. Nauka. Leningrad.

Koksharov, S.F. and Chemyakin, Yu.P. 1991: "Pamyatnik bronzovogo veka v okrestnostyakh derevni Saigatino". In Drevnie pogrebeniya Ob-Irtyshya. Izdatelstvo Omskogo Gosudarstvennogo Universiteta Omsk: 43-52.

Koksharov, S.F. and Stefanova, N.K. 1993: "Poselenie Volvoncha I na reke Konde". In Pamyatniki drevnei kultury Urala i Zapadnoi Sibiri. Voprosy arkheologii Urala 22. Nauka. Ekaterinburg: 54-67.

Kosarev, M.F. 1981: Bronzovy vek Zapadnoi Sibiri. Nauka. Moscow.

Kuzminykh, S.V. 2001: "O metalle epokhi bronzy poseleniya Palatki-1,-2". In Okhrannye arkheologicheskie issledovaniya na Srednem Urale 4. Bank kulturnoi informatsii. Yekaterinburg: 108-113.

Lunkov, V.Yu.; Orlovskaya, L.B. and Kuzminykh, S.V. 2009: "Rentgeno-flyuorescentnyj analiz: nachalo issledovanij himicheskogo sostava drevnego metalla". In Analiticheskie issledovanija laboratorii estestvennonauchnyh metodov 1. Institut arkheologii Rossijskoj Akademii nauk. Moscow.

Obydennov, M.F. and Shorin, A.F. 1995: Arkheologicheskie kultury pozdnego bronzovogo veka drevnikh uraltsev (cherkaskulskaya i mezhovskaya kultury). Izdatelstvo Uralskogo Gosudarstvennogo Universiteta. Yekaterinburg.

Panina, S.N. 2004: "Elizavetinsky tip keramiki. K postanovke problemy". In Chetvertye Bersovskie chteniya (Yekaterinburg, 2002). AKVA-PRESS. Yekaterinburg: 29-44.

Potemkina, T.M. 1985: Bronzovy vek lesostepnogo Pritobolya. Nauka. Moscow.

Salnikov, K.V. 1964: "Nekotorye voprosy istorii lesnogo Zauralya v epokhu Bronz". Voprosy arkheologii Urala 6: 5-23.

Serikov, Yu.B. 2007a: "Skalnye kultovye pamyatniki Shaitanskogo ozera". In Problemy arkheologii: Ural i Zapadnaya Sibir (k 70-letiyu T.M. Potemkinoi). Izdatelstvo Kurganskogo Gosudarstvennogo Universiteta. Kurgan: 42-49.

Serikov, Yu.B. 2007b: "Kultovye obekty i pamyatniki kak markery osvoennogo prostranstva (po materialam Srednego Zauralya)". In Mif, obryad i ritualny predmet $v$ drevnosti. Magellan. Yekaterinburg, Surgut: 224-233.

Serikov, Yu.V.; Korochkova, O.N.; Kuzminyj, S.V. y Stefanov, V.I. 2009: "Shaitanskoye Ozero II: new aspects of the Uralian Bronze Age". Archaeology, Ethnology \& Anthropology of Eurasia 37/2: 67-78.

Skochina, S.N. 2007: Rezultaty raskopok mnogosloinogo poseleniya Chepkul-5 (predvaritelnoe soobs-

T. P., 67, N. ${ }^{\circ} 2$, julio-diciembre 2010, pp. 489-499, ISSN: 0082-5638

doi: $10.3989 /$ tp. 2010.10052 
chenie). Vestnik arkheologii, antropologii $i$ etnografii (Tyumen) 8: 231-234.

Stefanov, V.I. 2006: "Mogilnik Tovkurtlor-3: Seiminsko-turbinski sled v Nizhnem Priobe". Rossiiskaya arkheologiya 1: 44-58.

Stefanov, V.I. and Korochkova, O.N. 2000: Andronovskie drevnosti Tyumenskogo Pritobolya. Poligrafist. Yekaterinburg.

Stefanova, N.K. and Koksharov, S.F. 1988: "Poselenie bronzovogo veka na reke Konde". Sovetskaya arkheologiya 3: 161-174.

Stokolos, V.S. 1972: Kultura naseleniya bronzovogo veka Yuzhnogo Zauralya. Nauka. Moscow.

Viktorova, V.D. 1999: "Koptyakovskaya kultura V gorno-lesnom Zaurale". In Treti Bersovskie chteniya: K 95-letiyu A.A. Bersa i 90-letiyu E.M. Bers. Materialy nauchno-praktichskoi konferentsii (Yekaterinburg, 1997). Bank kulturnoi informatsii. Yekaterinburg: 49-54.
Viktorova, V.D. 2001: "Pogrebalnye kompleksy na ostrove Kamennye Palatki". In Okhrannye arkheologicheskie issledovaniya na Srednem Urale 4. Bank kulturnoi informatsii. Yekaterinburg: 95-107.

Zakh, V.I. and Ivanov, S.N. 2006: "Kompleks epokhi bronzy mnogosloinogo poseleniya Chepkul-20 na severe Andreevskoi ozernoi sistemy". Vestnik arkheologii, antropologii $i$ etnografii (Tyumen) 7: 12-21.

Zakh, V.I. and Skochina, S.N. 2006: "Raskopki mnogosloinogo poseleniya Chepkul-20". Vestnik arkheologii, antropologii $i$ etnografii (Tyumen) 7: 231-234.

Zdanovich, D.G. and Kupriyanova, E.V. 2007: "Iz opyta issledovaniya pogrebalnykh kompleksov epokhi bronzy v Yuzhnom Zaurale: Mogilnik Stepnoe VII". In XVII Uralskoe arkheologicheskoe soveschanie: Materialy nauchnoi konferentsii (Yekaterinburg, 2007). Magellan. Yekaterinburg, Surgut: 140-143. 